GEOPHYSICAL RESEARCH LETTERS, VOL. 15, NO. 9, PAGES 961-964, AUGUST SUPPLEMENT 1988

\title{
PETROLOGICAL AND GEOCHEMICAL INVESTIGATIONS AT THE CAJON PASS DEEP DRILLHOLE
}

Leon T. Silver and Eric W. James

Division of Geological and Planetary Sciences, California Institute of Technology, Pasadena

Bruce W. Chappell

Department of Geology, Australian National University, Canberra, Australia

\begin{abstract}
Chemical analyses of cores from the Cajon Pass Deep Drillhole confirm vertical lithologic diversity of the basement rocks. They are metaluminous and calcalkaline; weak major element correlations with wide-ranging $\mathrm{SiO}_{2}$ suggest they are not a simple cogenetic suite. Quartz contents correlate with the thermal gradient profile, supporting conduction as the principal thermal transport mechanism. Abundances of heat producing elements are variable and somewhat lower than average crustal values. Cross-calibration with other measures of Th, $U$ and $K$ are underway. Ages of surface granitoids and core 17 are late Cretaceous; other plutonic rocks appear older but late Mesozoic. Initial lead isotopic signatures of the plutonic rocks change dramatically with depth in the hole.
\end{abstract}

\section{Introduction}

Petrological and geochemical investigations in the Cajon Pass Deep Drillhole (CPDDH) science experiment have the following objectives:

1) Acquisition of information on bulk rock mineral assemblages, compositions, fabrics and structures, heat production, thermal conductivity, fluid content, permeability, density, and recent geologic history related to the San Andreas fault;

2) Exploration, in the third dimension, of the petrological, geochemical and tectonic evolution of a critical part of southern California;

3) Direct testing and calibration of methods for downhole geophysical logging of physical and chemical properties of the rock column;

4) Observations on stability, sensitivity and range of mineral and isotopic systems, followed through a well-documented profile of temperature, pressure, and fluid chemistry to a depth of $5 \mathrm{~km}(1.6 \mathrm{~Kb})$.

The first phase of drilling to $2115 \mathrm{~m}$ and geophysical logging to a depth of $1829 \mathrm{~m}$ were completed March 28, and sample distributions were received by April 21, 1987. Silver and James (this volume) discuss the geologic setting and describe the lithologic column synthesized from cuttings, core, logs and other sources of information. In this paper we report and briefly discuss several groups of preliminary analytical results relevant to the objectives.

\section{Results and Discussion}

Petrographic analysis of the rocks involved preparation and examination of more than 120 rock and grain mount thinsections, estimation and point counting of mineral abundances, textural descriptions, and selection and preparation of samples for chemical analysis. We have used I.U.G.S. petrographic nomenclature (Streckeisen, 1973).

To demonstrate the lithologic diversity, estimated mineral modes typical of selected core samples are shown in table 1.

\section{Copyright 1988 by the American Geophysical Union.}

Paper number 8L7373.

0094-8276/88/008L-7373\$03.00
TABLE 1. Typical Estimated Modes of Cores (volume \%)

\begin{tabular}{ccccccc}
\multicolumn{8}{c}{ Core Number and Depth (m) } \\
5 & 10 & 15 & 17 & 18 & 19 & 20 \\
$521-$ & $743-$ & $1138-$ & $1351-$ & 1500 & $1652-$ & $1741-$ \\
529 & 746 & 1141 & 1357 & 1502 & 1658 & 1744
\end{tabular}

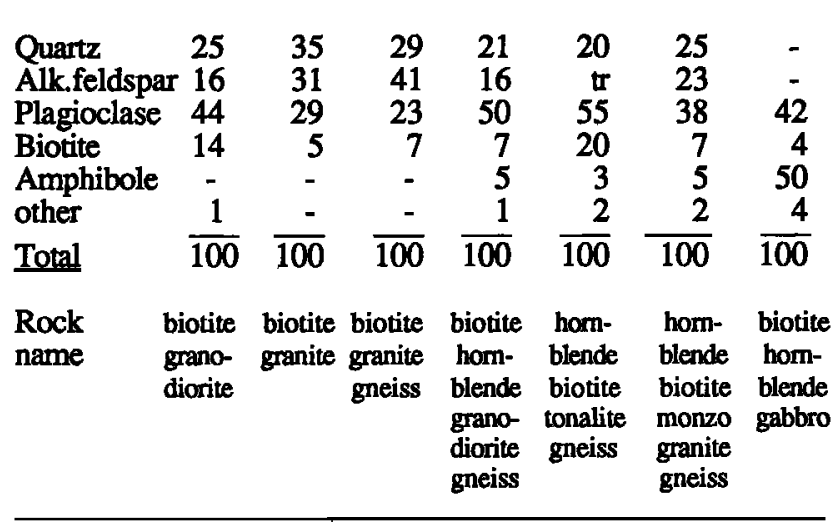

In addition to the major minerals, titanite is an ubiquitous accessory phase along with variable amounts of allanite, zircon, apatite and magnetite-ilmenite.

A number of representative core samples were prepared for major, trace element, and isotopic analyses. Samples were prepared from continuous vertical intervals of rock sawed as rods ( $\sim 3 \mathrm{~cm}$ square cross-sections) from the interior of the core bodies. Sample selection was based on criteria of primary rock character, relative freedom from alteration, and lithologic continuity over a significant depth interval to permit effective comparison with downhole gamma-ray and neutron activation chemical logs, as well as to produce materials for calibration of laboratory gamma-ray spectroscopy. Samples were broken down with a stellite diamond mortar and a Spex tungsten carbide "shatterbox", homogenized and aliquoted by seamless sample splitter for the various chemical studies. Major element analyses determined by $\mathrm{x}$-ray fluorescence and other methods and calculated C.I.P.W. normative mineral values are presented in table 2. The potassium from these data, uranium and thorium determined by isotope dilution mass spectrometry, and total gamma ray activity in API units are found in table 3 .

The range of rock compositions is also represented in Figure 1, a plot of the total alkalies versus $\mathrm{SiO}_{2}$ and $\mathrm{CaO}$ versus $\mathrm{SiO}_{2}$ combined in a Peacock diagram. The intersection of the two arrays, represented by the vertical line indicates the rocks are generally calkalkaline in character. However, the scatter of the linear arrays suggests the rocks may not be a simple cogenetic suite. Several of the samples are more alkaline. This inference is supported by petrographic properties as well. All of the rocks are metaluminous.

The modes and the normative analyses indicate great variability in quartz content in the cores. The importance of 
TABLE 2. Chemical analyses and C.I.P.W. Norms of Cajon Pass Deep Drillhole Cores (weight \% by XRF and other methods). Analyst: B. W. Chappell, A. N. U.

Core Number and Sample Interval (m)

$\begin{array}{ccccccc}5 & 10 & 15 & 17 & 18 & 19 & 20 \\ 525.57 & 744.44 & 1138.98 & 1352.85 & 1500.68 & 1655.61 & 1741.05 \\ 525.71 & 744.93 & 1140.26 & 1353.31 & 1501.35 & 1657.29 & 1741.35\end{array}$

\begin{tabular}{lrrrrrrr}
$\mathrm{SiO}_{2}$ & 66.39 & 73.30 & 71.10 & 62.92 & 61.10 & 67.21 & 44.69 \\
$\mathrm{TiO}_{2}$ & 0.63 & 0.32 & 0.46 & 0.88 & 1.07 & 0.56 & 1.30 \\
$\mathrm{Al}_{2} \mathrm{O}_{3}$ & 16.01 & 13.98 & 14.01 & 17.30 & 15.15 & 15.75 & 18.98 \\
$\mathrm{Fe}_{2} \mathrm{O}_{3}$ & 1.17 & 0.70 & 1.45 & 1.86 & 1.75 & 1.31 & 4.28 \\
$\mathrm{FeO}$ & 2.21 & 1.10 & 1.75 & 2.66 & 5.17 & 1.94 & 7.39 \\
$\mathrm{MnO}$ & 0.07 & 0.05 & 0.05 & 0.06 & 0.10 & 0.08 & 0.17 \\
$\mathrm{MgO}$ & 1.40 & 0.56 & 0.64 & 1.76 & 3.50 & 1.10 & 6.06 \\
$\mathrm{CaO}$ & 3.13 & 1.79 & 1.88 & 4.73 & 3.47 & 3.24 & 11.54 \\
$\mathrm{Na}_{2} \mathrm{O}$ & 3.73 & 3.37 & 3.00 & 4.25 & 3.33 & 3.80 & 2.83 \\
$\mathrm{~K}_{2} \mathrm{O}$ & 3.19 & 4.45 & 4.81 & 2.38 & 3.44 & 4.29 & 0.89 \\
$\mathrm{P}_{2} \mathrm{O}_{5}$ & 0.19 & 0.08 & 0.13 & 0.29 & 0.21 & 0.15 & 0.33 \\
$\mathrm{~S}$ & $\leq 0.01$ & $<0.01$ & $\underline{0.02}$ & $\leq 0.01$ & 0.06 & $\underline{0.06}$ & $\underline{0.39}$ \\
\hline
\end{tabular}
$\begin{array}{llllllll}\text { Totals } & 98.13 & 99.71 & 99.30 & \frac{0.01}{99.10} & 98.35 & 90.49 & 98.85\end{array}$

\section{C.I.P.W. NORMS}

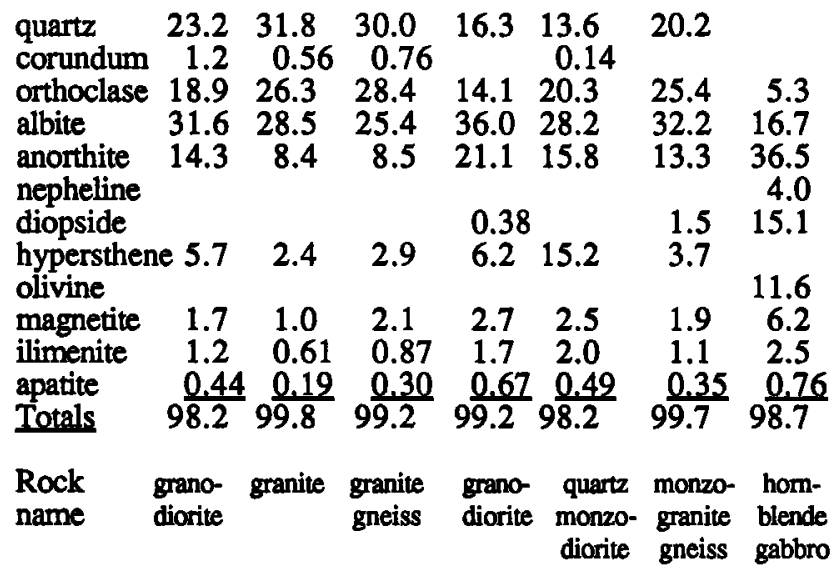

quartz content in determining rock thermal conductivity is well established. Temperature gradient measurements (Lachenbruch and Sass, this volume) correspond closely to the lithologic differences we report. Figure 2 shows a comparison of quartz content in basement cores of leg 1 with the observed temperature gradient. This demonstrates that conductivity is the principal heat transfer mechanism. The variability observed in core and cuttings studies (Silver and James, this volume) points to the requirement for close sample and logging control for effective heat flow calculations.

The distribution of heat producing radioactive elements in the several core samples analyzed is variable (table 3 ) and generally somewhat lower than average crust. This reflects, in particular, lower uranium values (which average $1.6 \mathrm{ppm}$ ) compared to average crustal values of $\sim 3-4 \mathrm{ppm}$. The Th values are close to average crustal values and potassium values show a normal range. Whether the low $U$ values observed reflect original endowments or secondary modifications of the rocks is under investigation in our laboratory. For core 17, we have compared the total rock radiogenic $\mathrm{Pb}$ isotope increments with the observed $\mathrm{U}$ and $\mathrm{Th}$ and have found no evidence for major U loss.

In table 3 we also calculate heat production values for the

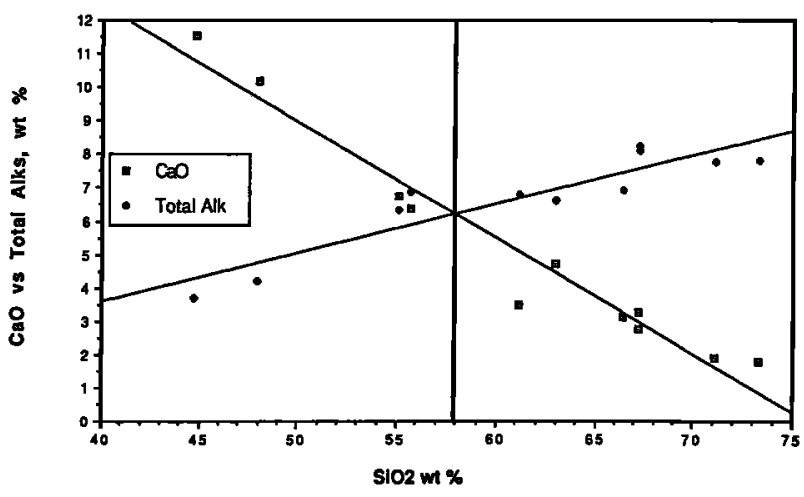

Fig. 1. Peacock diagram, $\mathrm{CaO}$ versus $\mathrm{SiO}_{2}$ and total alkalies versus $\mathrm{SiO}_{2}$ in weight percent. Vertical line at the intersection of the best-fit lines suggests the rocks are generally calkalkaline.

seven samples. The somewhat low values indicate that local heat production can be treated effectively in the evaluation of the tectonic contribution to heat flow at Cajon Pass.

The Th/U ratios observed are higher than "average" crustal values but they are not unusual for the Precambrian and Mesozoic granites of the Mojave Desert region which have

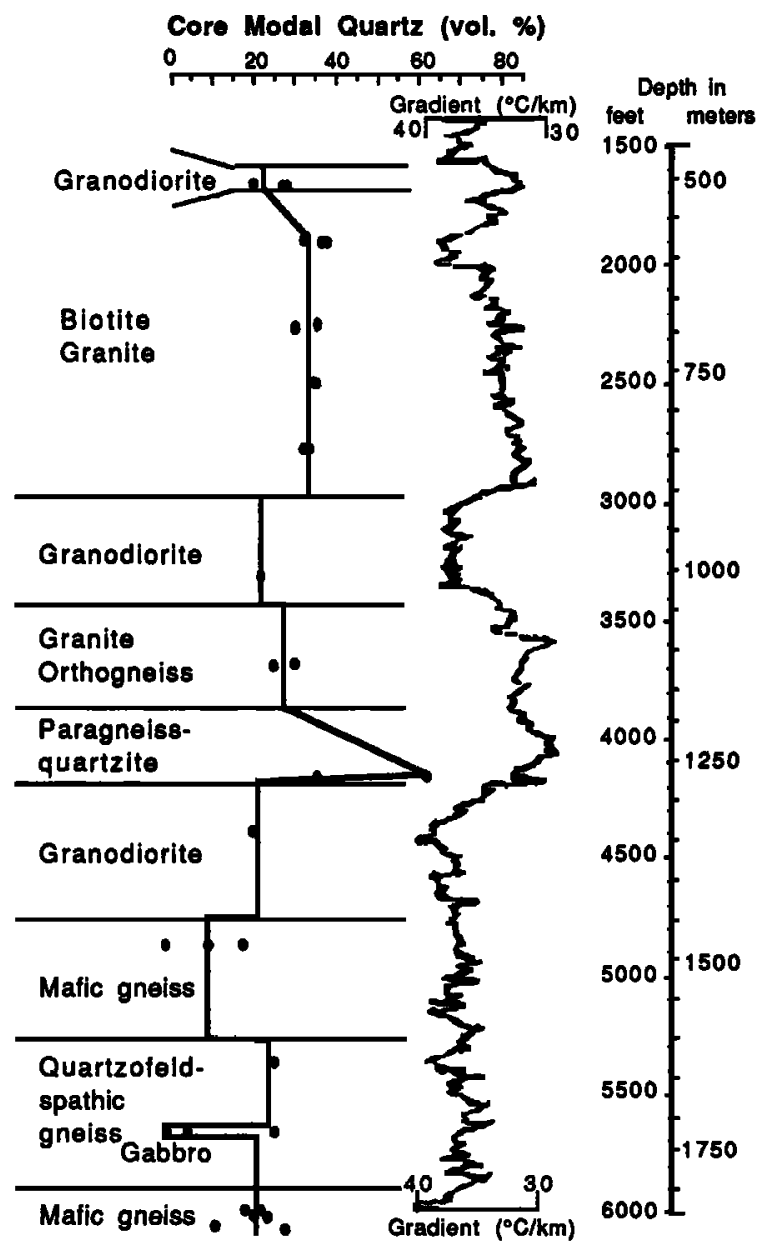

Fig. 2.Modal (volume \%) quartz in core samples compared to temperature gradient (Lachenbruch and Sass, this volume) in the Cajon Pass drillhole basement rocks. 
TABLE 3. Radioactive Element Abundances

\begin{tabular}{|c|c|c|c|c|c|c|}
\hline $\begin{array}{l}\text { Core } \\
\text { Sample }\end{array}$ & $\begin{array}{l}\mathrm{K} \\
\%\end{array}$ & $\begin{array}{c}\mathrm{U} \\
\mathrm{ppm}\end{array}$ & $\begin{array}{l}\text { Th } \\
\text { ppm }\end{array}$ & $\mathrm{Th} / \mathrm{U}$ & $\begin{array}{c}\text { Total } \\
\text { API } \boldsymbol{\gamma}^{1}\end{array}$ & $\begin{array}{c}\text { Heat } \\
\text { Production } 2 \\
\mu \mathrm{W} / \mathrm{m}^{3}\end{array}$ \\
\hline $\begin{array}{l}\text { C-5 } \\
\text { C-10 } \\
\text { C-15 } \\
\text { C-17 } \\
\text { C-18 } \\
\text { C-19 } \\
\text { C-20 }\end{array}$ & $\begin{array}{l}2.64 \\
3.69 \\
3.99 \\
1.97 \\
2.85 \\
3.56 \\
0.74\end{array}$ & $\begin{array}{l}1.91 \\
1.01 \\
1.23 \\
1.25 \\
1.67 \\
3.80 \\
0.32\end{array}$ & $\begin{array}{r}13.35 \\
13.45 \\
22.68 \\
7.14 \\
14.41 \\
10.98 \\
0.34\end{array}$ & $\begin{array}{r}6.97 \\
13.30 \\
18.51 \\
5.17 \\
8.63 \\
2.89 \\
1.05\end{array}$ & $\begin{array}{r}85 \\
107 \\
179 \\
68 \\
101 \\
168 \\
28\end{array}$ & $\begin{array}{l}1.76 \\
1.58 \\
2.35 \\
1.06 \\
1.82 \\
2.16 \\
0.20\end{array}$ \\
\hline
\end{tabular}

1Measured with a Core Laboratories, Inc. total gamma activity scintillometer, calibrated with the manufacturer's synthetic standards.

2 Based on energies of Wetherill (1966) revised for accepted decay constants and corrected for measured core densities.

been cited for their distinctive high $\mathrm{Th} / \mathrm{U}$ rock ratios (e.g. Silver et al., 1984). If uranium loss has influenced the present $\mathrm{Th} / \mathrm{U}$ ratios in Cajon Pass rocks it should be identified by the techniques and arguments for the origin and timing of uranium mobility in granites (Silver, 1982; Silver et al., 1981,1984) now being applied to Cajon Pass core samples.

The Cajon Pass project provides an unsurpassed opportunity for cross-calibration of various methods for determining $\mathrm{U}$, Th and potassium abundances in a crustal column. We report here, with the cooperation of colleagues (Anderson et al., this volume), a preliminary comparison of our isotope dilution and XRF determinations of these elements with values derived from downhole spectral gamma-ray logging. In Figure 3, the data is presented with a reference 1:1 ratio line, a regression line fitted to the data, and $R^{2}\left(R^{\wedge} 2\right)$, a measure of the goodness of fit. There are both scatter and significant departures from a 1:1 fit for all three elements. These can be attributed to several possible sources, including sampling procedures, chemical and isotopic analytical techniques, the gamma ray statistics, and the spectral stripping and calibration methods used in processing the downhole logging data. For some parts of the column, uranium series disequilibrium is suspected. Nevertheless, we believe this first iteration in a continuing effort at cross calibration promises a refinement in downhole methodology which will be very important in future basement logging studies. Other collaborative calibration efforts are now in progress for downhole neutron activation chemical logging and for laboratory gamma-ray spectrometry.

As part of an extensive isotope geochemistry effort now underway we report preliminary $\mathrm{U}-\mathrm{Th}-\mathrm{Pb}$ geochronological results on zircons and sphenes from several nearby surface samples and for a sphene-hornblende biotite granodiorite from

TABLE 4. Zircon and Sphene U-Th-Pb Apparent Ages

\begin{tabular}{lccc}
\hline Sample & $\begin{array}{c}\text { Zircon U-Pb } \\
\text { intercept age } \\
\pm 2 \mathrm{Ma}\end{array}$ & $\begin{array}{c}206 \mathrm{~Pb} / 238 \mathrm{U} \\
\pm 3 \mathrm{Ma}\end{array}$ & $\begin{array}{c}{ }^{208} \mathrm{~Pb} / 232 \mathrm{Th} \\
\pm 3 \mathrm{Ma}\end{array}$ \\
\hline & & & \\
Squaw Peak & 80.6 & 76.7 & 77.3 \\
Whale Mountain & 74.9 & 74.2 & 82.4 \\
Silverwood Lake & 75.6 & - & - \\
Core 17 & 78.3 & 75.4 & 76.3 \\
Average & 77.3 & 75.4 & 78.6 \\
\hline
\end{tabular}
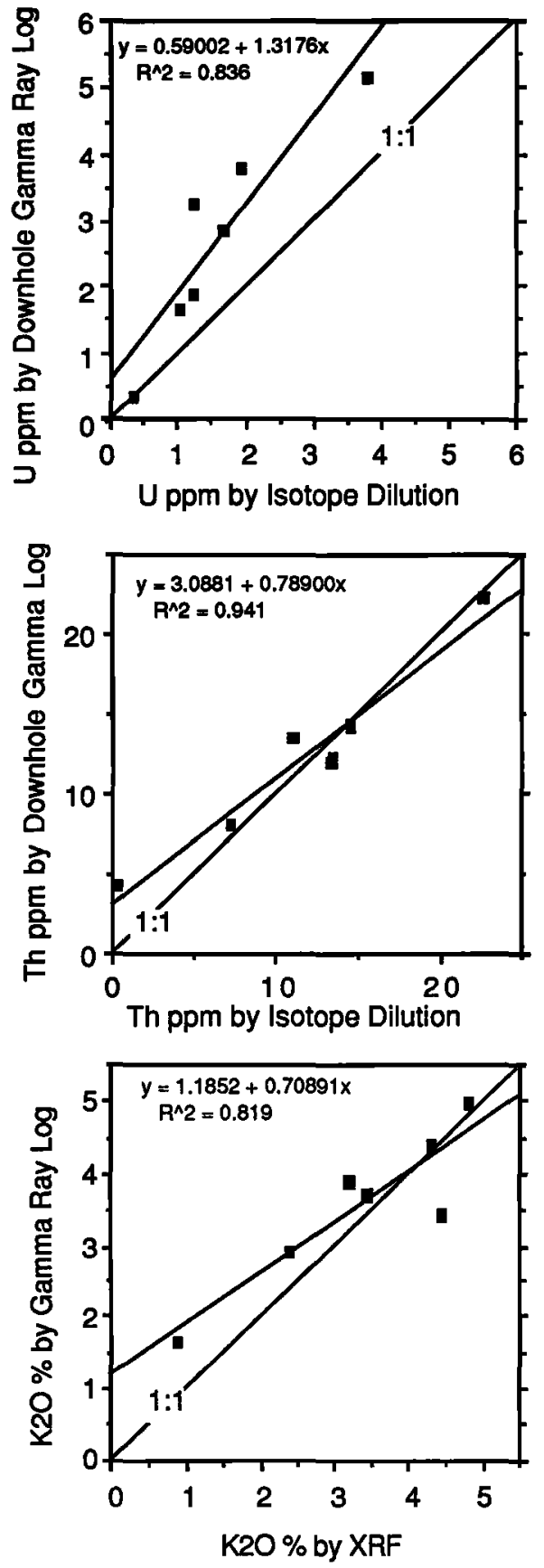

Fig. 3. Comparison of ppm $\mathrm{U}, \mathrm{ppm} \mathrm{Th}$, and $\% \mathrm{~K}_{2} \mathrm{O}$ on core samples by isotope dilution and $\mathrm{x}$-ray fluorescence with measurements on matched downhole intervals by gamma-ray logging. $R^{\wedge} 2$ is a measure of the goodness of fit of the line regressed through the data.

core $17(1352.9-1353.3 \mathrm{~m})$ Surface granodiorites were collected from Squaw Peak, $1.2 \mathrm{~km}$ to the south of CPDDH, Whale Mountain, $2.4 \mathrm{~km}$ southwest, and from Silverwood Lake, $13 \mathrm{~km}$ to the east (table 4).

All of the zircon ages are based upon multiple zircon fractions which display moderate inheritance effects. The reported ages are based on intercept arrays on a concordia diagram where the lower intercept is closely controlled. Uncertainties are given in the table. The sphene leads are only moderately radiogenic and are corrected with feldspar initial leads. The observed ${ }^{207} \mathrm{~Pb} /{ }^{204} \mathrm{~Pb}$ ratios do not permit calculation of 

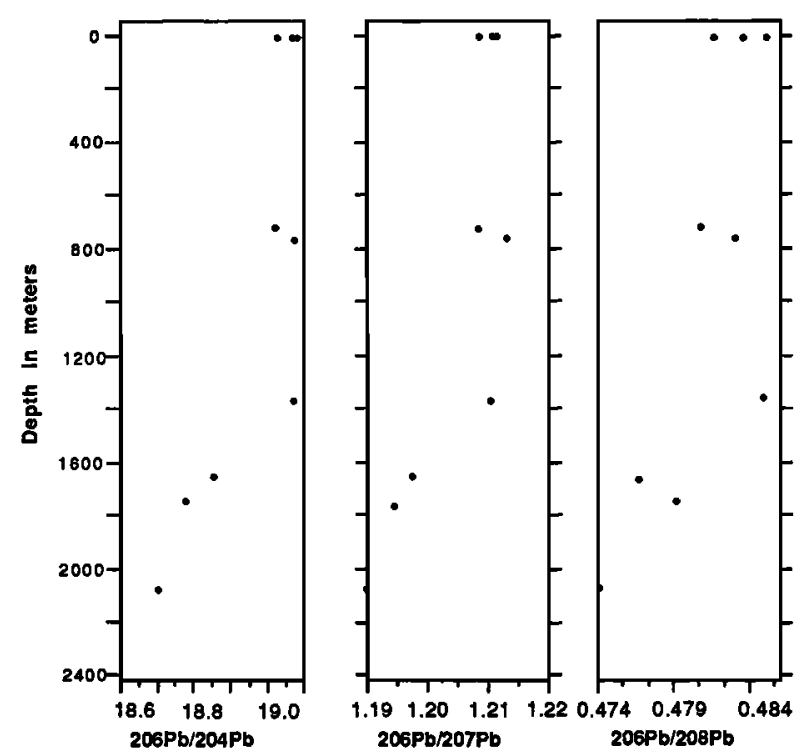

Fig. 4. Variation of feldspar initial lead isotopic ratios in core and surface samples with depth in the Cajon Pass deep drillhole.

significant $207 \mathrm{~Pb} / 206 \mathrm{~Pb}$ and ${ }^{207} \mathrm{~Pb} / 235 \mathrm{U}$ ages, therefore only $206 \mathrm{~Pb} / 238 \mathrm{U}$ and $208 \mathrm{~Pb} / 232 \mathrm{Th}$ ages are reported.

It is apparent that core 17 , believed to be the youngest intrusive encountered in the well on petrographic grounds, is of the same generation as the three surface samples, all falling within 75-81Ma. Sphene ages are in good agreement within assigned error limits and support the interpretation of late Cretaceous emplacement for the family of granodiorites in this area. Miller and Morton (1980) report K-Ar ages on biotites from granodiorites from $3.2 \mathrm{~km}$ south and $11.3 \mathrm{~km}$ east of CPDDH, of 70.0 and $70.5 \mathrm{Ma}$, respectively. These are plausible cooling ages $\left(<300^{\circ} \mathrm{C}\right)$ for the last plutonic activity in the rocks near the site.

Finally, in Figure 4, the isotopic composition of leads from feldspars from the three surface samples and from cores $9,10,17,19,20$, and 33 are given as a function of depth. From our preliminary work all appear to be Mesozoic plutonic rocks. The leads of the three highest core samples are similar to the three regionally characteristic surface samples. Cores 19,20 , and 33 , however, are in notable contrast in their more primitive, less radiogenic character. Such contrasts in rocks of approximately equivalent age are known only in leads formed in quite different lithospheric settings (Zartman, 1974; Silver, 1987). No other instance of such a drastic change in initial lead compositions in a vertical column has been reported, to our knowledge. In this preliminary report, awaiting our further work on the precise ages of each of the rock units, we can suggest as one possibility the large-scale tectonic juxtaposition of rocks which originally formed in quite different settings. Other altematives will be explored collectively in a later more definitive paper.

Acknowledgements. We wish to acknowledge the U.S.G.S. staff at Cajon Pass, particularly W. Campbell, F.Raup, D.
Volturno and $\mathrm{W}$. Linenburger, for measurements of core gamma ray activity. R. Anderson, of Lamont-Doherty Geological Observatory, and J. Sass and A. Lachenbruch, of the U.S.G.S., freely exchanged data on downhole measurements of gamma-ray activity and temperature gradients. Spencer Cotkin provided editorial review. This work supported by the National Science Foundation and DOSECC. Contribution number 4663, Division of Geological and Planetary Sciences, California Institute of Technology.

\section{References}

Anderson, R., Dove, R., Silver, L., and James, E., Geochemical well logs from the Cajon Pass Scientific Drillhole, California I: elemental and mineralogical analyses from logs and their preliminary comparison with core analyses, Geophys. Res. Lett., this volume. 1988.

Lachenbruch, A.H., and Sass, J.H., The stress heat-flow paradox and thermal results from Cajon Pass: Geophys. Res. Lett., this volume. 1988.

Miller, F.K. and Morton, D.M., Potassium-argon geochronology of the Eastern Transverse Ranges and southern Mojave Desert, Southern California, U.S. Geol.Survey Prof. Pap. 1152, 30p., 1980.

Silver, L.T, Lead Isotopes and petrogenesis of cordilleran batholiths, Geol. Soc. Am. Abs. with Prog., 19, 845, 1987.

Silver, L.T., A note of the magnitude of possible uranium losses from granites of the conterminous United States, Symp.on U Explor.Methods, NEA-IAEA, Paris, 457, 1-4 June 1982.

Silver, L.T., and James, E.W., Geologic setting and lithologic column of the Cajon Pass Deep Drillhole, Geophys. Res. Lett., this volume, 1988.

Silver, L.T., Williams, I. S., and Woodhead, J.A., Uranium in granites from the southwestern United States: actinide parent-daughter systems, sites and mobilization, 1st year report, DOE-GBX-45(81), Calif. Institute Tech., 380p., 1981 .

Silver, L.T., Woodhead, J.A., Williams, I. S., and Chappell, B.W., Uranium in granites from the Southwestern United States: actinide parent-daughter systems, sites and mobilization, 2ed year report, DOE-GJBX-7(84), Calif. Institute Tech., 431 p., 1984.

Streckeisen, A.L., Plutonic rocks, classification and nomenclature recommended by the IUGS subcommission on the systematics of igneous rocks: Geotimes, 18, 26, 1973.

Wetherill, G.W., Radioactive decay constants and energies, in The Handbook of Physical Constants, S.P. Clark, Jr. ed., Geol. Soc Ameica Memoir 97, 513, 1966.

Zartman, R.E., Lead isotopic provinces in the Cordilleran of the western United States and their geologic significance: Economic Geology, 69, 792, 1974.

Eric W. James and Leon T. Silver, Division of Geological and Planetary Sciences, 170-25, California Institute of Technology, Pasadena, CA 91125.

(Received April 15, 1988;

revised July 14, 1988;

accepted July 14, 1988.) 